\title{
Możliwości zmiany istotnych dla środowiska parametrów eksploatacyjnych spalinowych lokomotyw 6-osiowych przez modernizację zespolów
}

\begin{abstract}
Wykorzystywane do prowadzenia pociagów towarowych oraz ciężkich prac manewrowych sześcioosiowe lokomotywy sa przestarzate technicznie i niekorzystnie wptywaja na środowisko. $W$ artykule przedstawiono nowe i zmodernizowane ukta$d y$, systemy i zespoty, które zostanq zastosowane $w$ platformie zmodernizowanych lokomotyw. Na przykładzie wybranego typu loko-motywy, przedstawiono różnice pomiędzy eksploatowanym taborem a zmodernizowanym, w odniesieniu do oddziatywania na środowisko i spetnienie wymagań Unii Europejskiej. Przed-stawiono również koncepcje zabudowy nowych urzqdzeń i zespołów w modułowej konstrukcji nadwozia.

Artykut powstat $w$ ramach realizowanego projektu Programu Badań Stosowanych 3 nr PBS3/B6/33/2015 pt.: „Platforma zmodernizowanych spalinowych lokomotyw 6-osiowych spetniajacych wymagania Unii Europejskiej z wykorzystaniem lokomotyw eksploatowanych w kraju" wykonywanego przez Instytut Pojazdów Szynowych 'TABOR” w Poznaniu i Pojazdy Szynowe ,PESA” Bydgoszcz S.A.
\end{abstract}

\section{Wstęp}

Wymagania jakie są obecnie stawiane nowym spalinowym lokomotywom, wymuszają na przewoźnikach dostosowanie również modernizowanego taboru (głównie modernizacji polegającej na wymianie agregatów prą̧dotwórczych) do obowiązujących kryteriów.

Wiąże się to przede wszystkim z ograniczeniem szkodliwego oddziaływania na środowisko naturalne przestarzałych silników spalinowych oraz pośrednio ze zmniejszeniem jednostkowego zużycia paliwa.

$\mathrm{Na}$ chwilę obecną park maszynowy lokomotyw 6osiowych w Polsce jest przestarzały. Wielu użytkowników częściej skłania się w kierunku realizacji procesu modernizacji lokomotyw będących w eksploatacji, niż decyduje na zakup nowych lokomotyw spalinowych z uwagi na wyższe koszty.

Podstawą rozpoczęcia procesu modernizacji lokomotywy spalinowej jest osiagnięcie parametrów dorównujących nowym lokomotywom znajdującym się obecnie $w$ ofercie czołowych producentów taboru tj. [3]:

- zachowanie równowagi pomiędzy poziomem technicznym lokomotywy modernizowanej a nowej

- spełnienie wymagań w zakresie komfortu obsługi lokomotyw przez maszynistów jak i obsługi serwisowej

- zmniejszenie zużycia oleju napędowego i środków smarnych
- zmniejszenie szkodliwego oddziaływania na środowisko naturalne:

a) zmniejszenie emisji do atmosfery składników toksycznych spalin takich jak $\mathrm{CO}, \mathrm{HC}, \mathrm{NO}_{\mathrm{x}}$

b) zmniejszenie emisji cząstek stałych

c) zmniejszenie wydzielania $\mathrm{CO} 2$ do atmosfery

d) ograniczenie emisji hałasu wewnętrznego i zewnętrznego

e) ograniczenie pola magnetycznego $\mathrm{w}$ kabinach sterowniczych.

Modernizacja lokomotywy spalinowej wiąże się również z [4]:

- zastosowaniem nowoczesnych i trwałych aparatów, urządzeń i elementów o wydłużonym czasie eksploatacji'

- zwiększeniem przebiegów eksploatacyjnych pomiędzy przeglądami

- poprawą komfortu obsługi i bezpieczeństwa w kabinach

- poprawą widoczności sygnałów ze stanowiska sterowniczego.

Do znanych serii (typów) lokomotyw spalinowych 6-osiowych wykorzystywanych przez operatorów kolejowych zaliczyć należy:

- lokomotywy serii SM31

- lokomotywy serii SM48 (TEM2)

- lokomotywy serii ST43 
- lokomotywy serii ST44

- lokomotywy serii SP45.

Przeprowadzona analiza efektywności modernizacji wszystkich spalinowych lokomotyw 6-osiowych wymienionych powyżej w oparciu o analizy cyklu trwałości LCC wykazała, że pełna efektywność ekonomiczna i techniczna zostanie osiagnięta w przypad$\mathrm{ku}$ jednoczesnej modernizacji platformy lokomotyw obejmujących lokomotywę liniową serii ST44 (typu M62) i lokomotywę manewrową serii SM48 (typu TEM2). Stanowią one najliczniejszą grupę w eksploatacji a ponadto zostały zabudowane na jednym podwoziu obejmującym zarówno ostoję jak i układy biegowe (wózki). Przy tym zakładamy, że modernizacja dotyczyć będzie wszystkich najważniejszych węzłów i układów.

Obecnie Instytut Pojazdów Szynowych TABOR oraz PESA realizują wspólnie projekt modernizacji platformy lokomotyw spalinowych. Po procesie modernizacji lokomotywy będą eksploatowane z oznaczeniem typu 19D. Wdrożenie projektu odbywa się na bazie lokomotywy SM48/TEM2.

Lokomotywa SM48 (przemysłowe oznaczenie TEM2) jest jednokabinową lokomotywą o mocy 880 kW z przekładnią elektryczną, przeznaczoną do obsługi wschodnich rejonów przygranicznych w pracach przeładunkowych, ciężkich pracach manewrowych, a także (po zabudowie polskich systemów bezpieczeństwa) również do prowadzenia liniowych pociagów towarowych.

Lokomotywy były przygotowane do prac na torach o szerokości $1435 \mathrm{~mm}$ lub $1520 \mathrm{~mm}$ i były sprowadzane do Polski z byłego ZSRR od 1974 r. zarówno na potrzeby PKP jak i potrzeby kolei przemysłowych. Ogółem zakupiono 130 lokomotyw do PKP (na tor normalny i szeroki) oraz około 300 lokomotyw dla kopalni, hut, zakładów górniczych i przedsiębiorstw transportu kolejowego.
2. Nowe i zmodernizowane układy, systemy i zespoły platformy lokomotyw

Platforma lokomotyw sześcioosiowych na bazie lokomotywy TEM2/SM48 obejmować będzie cztery podstawowe kombinacje lokomotyw. Będą to dwie lokomotywy o mocy $1800 \mathrm{~kW}$ i $1500 \mathrm{~kW}$ występujące w wersji normalnotorowej i szerokotorowej.

Wstępną koncepcję rozmieszczenia urządzeń $\mathrm{w}$ lokomotywie 19D przedstawiono na rys. 1 .

Projekt modernizacji lokomotywy zakłada:

- pozostawienie bez znaczących zmian ostoi lokomotywy, która poddana zostanie naprawie głównej i modyfikacjom pozwalającym na zabudowę nowego układu nadwozia

- zmianę układu dźwigniowego hamulca na wózku w celu poprawienia skuteczności hamowania oraz zabudowę hamulca sprężynowego

- wymianę nadwozia lokomotywy na zupełnie nowe o budowie modułowej

- wymianę zespołu prądotwórczego

- zabudowę nowoczesnych układów pomocniczych (sprężarki, wentylatorów silników trakcyjnych, układu chłodzenia) napędzanych silnikami prądu przemiennego i hydrostatycznymi

- zabudowę nowoczesnego systemu sterowania mikroprocesorowego lokomotywy z układem rozproszonych sterowników.

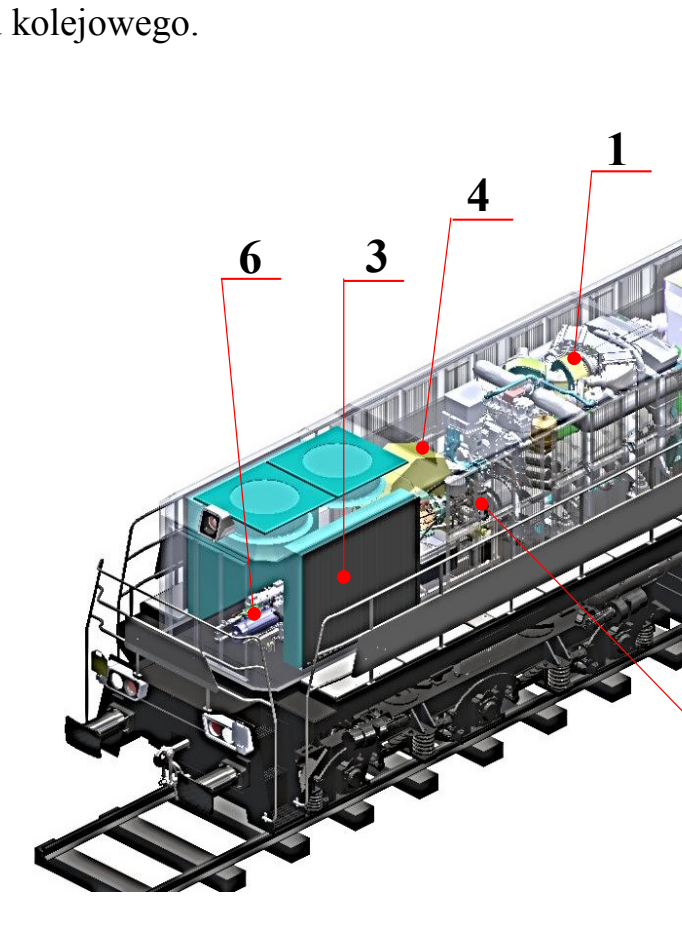

2

20

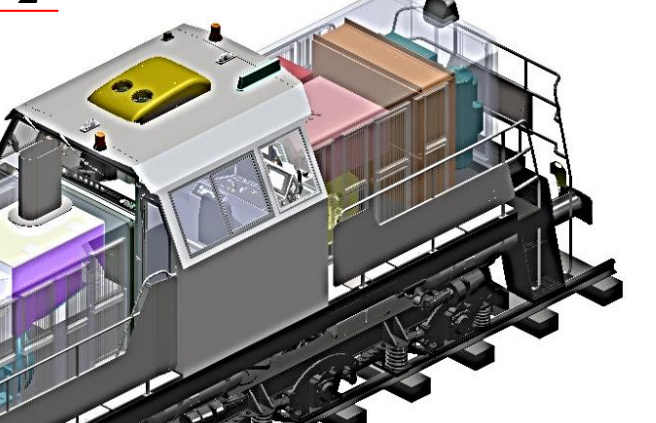


1 - Zespół prądotwórczy

2 - Tłumik wylotu spalin filtr

3 - Zespół chłodnic

4 - Wentylator silników trakc

5 - Sprężarka z układem uzda

6 - Zespół podgrzewczy WEE

7 - Szafa NN

8 - Szafa SN

9 - Szafa przetwornic

10 - Tablica pneumatyczna

Rys. 1. Koncepcja rozmieszczenia urządzeń w lokomotywie 19D

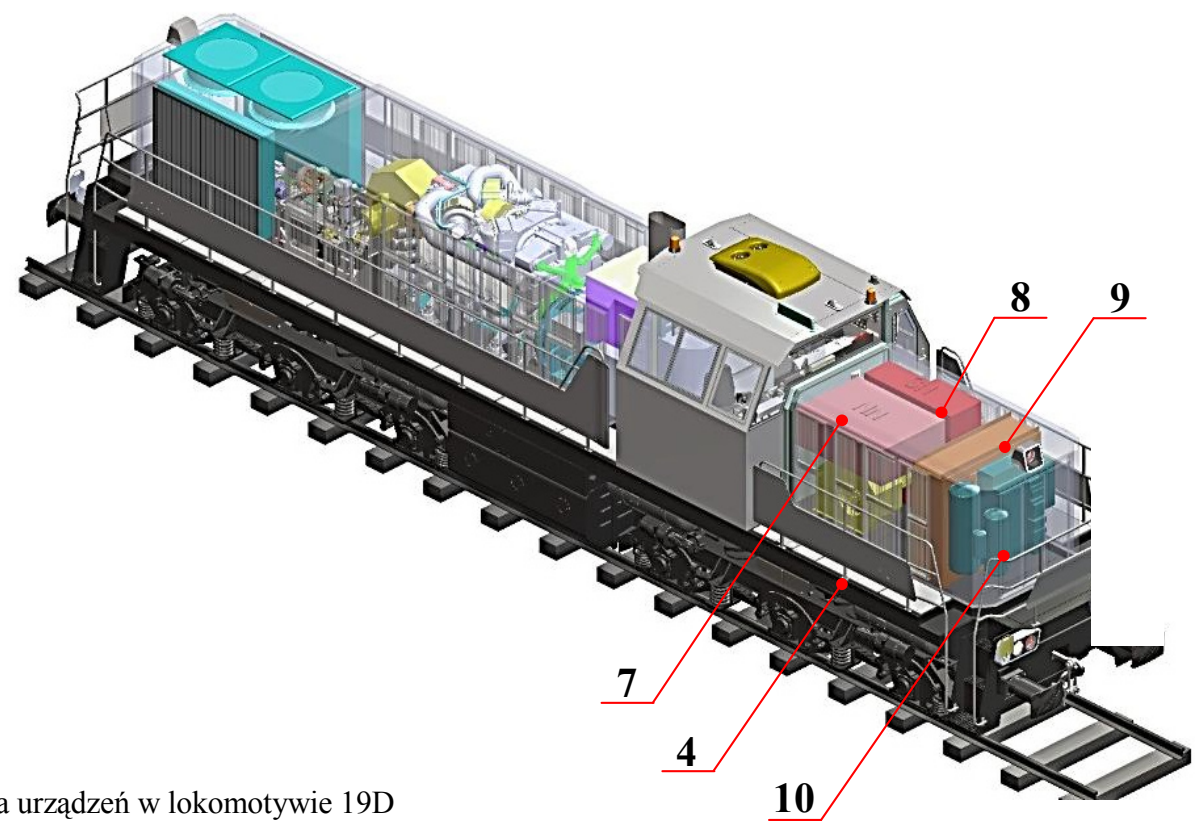

3. Glówne parametry techniczne lokomotywy 19D (SM48) przed i po modernizacji.

Tabela 1

\begin{tabular}{|c|c|c|c|}
\hline \multirow{2}{*}{ Nazwa parametru lub wielkości } & \multirow{2}{*}{$\begin{array}{c}\text { Jedno- } \\
\text { stka }\end{array}$} & \multicolumn{2}{|c|}{ Wartości parametru lub wielkości } \\
\hline & & przed modernizacją & po modernizacji \\
\hline Oznaczenie lokomotywy & - & SM48 (TEM2) & 19D (SM48) \\
\hline Szerokość toru & $\mathrm{Mm}$ & \multicolumn{2}{|c|}{$\frac{1}{1435}$} \\
\hline Rodzaj pracy & - & manewrowa & manewrowo-liniowa \\
\hline Układ osi & - & \multicolumn{2}{|c|}{$\mathrm{Co}-\mathrm{Co}$} \\
\hline Nacisk osi na szynę & - & \multicolumn{2}{|c|}{$19,3+3 \%$} \\
\hline Prędkość max. & $\mathrm{km} / \mathrm{h}$ & \multicolumn{2}{|c|}{100} \\
\hline Moc lokomotywy & $\mathrm{kW}$ & 820 & $1800 / 1500$ \\
\hline Rodzaj silnika wysokoprężnego & - & $\begin{array}{l}\text { pionowy, cztero-suwowy, z } \\
\text { doładowa-niem turbosprężarką } \\
\text { i między stopniowym } \\
\text { chłodzeniem powietrza } \\
\text { doładowania typu PD1M }\end{array}$ & $\begin{array}{c}\text { wysokoprężny } \\
12 \text { cylindrowy, } \\
\text { w układzie } \mathrm{V}-90 \\
\text { z elektronicznym } \\
\text { systemem wtrysku paliwa z } \\
\text { trzema turbosprężarkami, } \\
\text { typu } 12 \mathrm{~V} 4000\end{array}$ \\
\hline System sterowania & - & oporowy & $\begin{array}{c}\text { elektroniczny } \\
\text { mikroprocesorowy }\end{array}$ \\
\hline
\end{tabular}

Platforma zmodernizowanych lokomotyw typu 19D będzie się charakteryzować następującymi rozwiązaniami:

- nowoczesnymi silnikami spalinowymi spełniającymi wymagania etapu IIIB (zgodnie z wymogami Dyrektywy 2004/26/WE Parlamentu Europejskiego w zakresie ograniczenia emisji zanieczyszczeń gazowych i cząstek stałych do atmosfery

- nowoczesnym zespołem prądnic synchronicznych (główna, pomocnicza)

- układem elektrycznym spełniającym wymagania w zakresie zakłóceń i hałasu

- napędami o zwiększonej mocy pozwalającymi na zwiększenie możliwości przywozowych oraz napędami pomocniczymi z wykorzystaniem silników prądu zmiennego i silników hydraulicznych [6]
- mikroprocesorowym układem sterowania i diagnostyki napędem i całą lokomotywą

- nowoczesną kabiną sterowniczą z niezależnymi układami pulpit-fotel, $\mathrm{z}$ nową izolacją akustyczną i termiczną oraz wyłożeniami, wyposażoną w klimatyzator (lub schładzacz) oraz innymi urządzeniami poprawiającymi komfort obsługi

- zmodernizowanymi wózkami trakcyjnymi w zakresie prowadzenia zestawów kołowych poprawiających oddziaływanie na tor, poprawioną szczelnością przekładni głównej, zwiększoną trwałością obręczy (w wyniku wprowadzenia systemów smarowania obrzeży kół) oraz polepszoną trwałością silników trakcyjnych (zmiana izolacji) 
- nowoczesnymi systemami wykrywania, sygnalizacji i gaszenia ewentualnego pożaru przedziałów maszynowych.

Widok lokomotywy przed modernizacją przedstawiono na rys. 2. Przewidywany wygląd po modernizacji przedstawiono na rys. 3 .
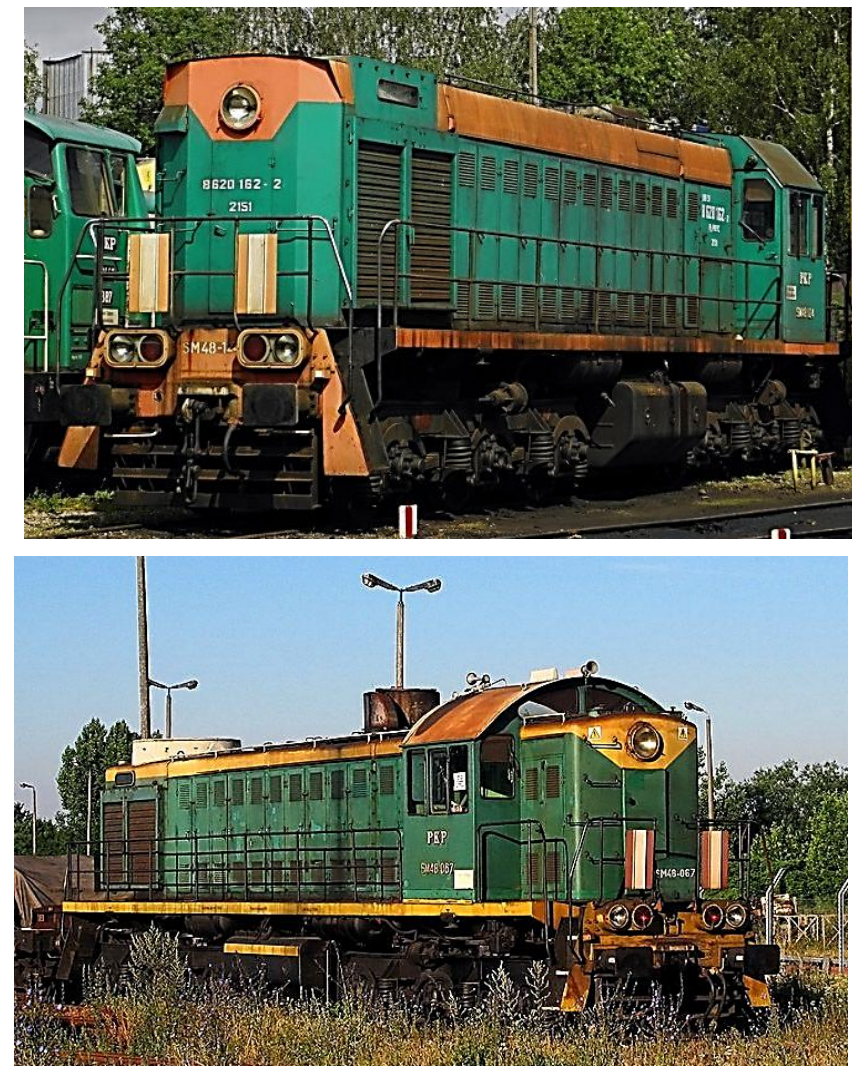

Rys. 2. Widok lokomotywy SM48 (TEM2) przed modernizacją
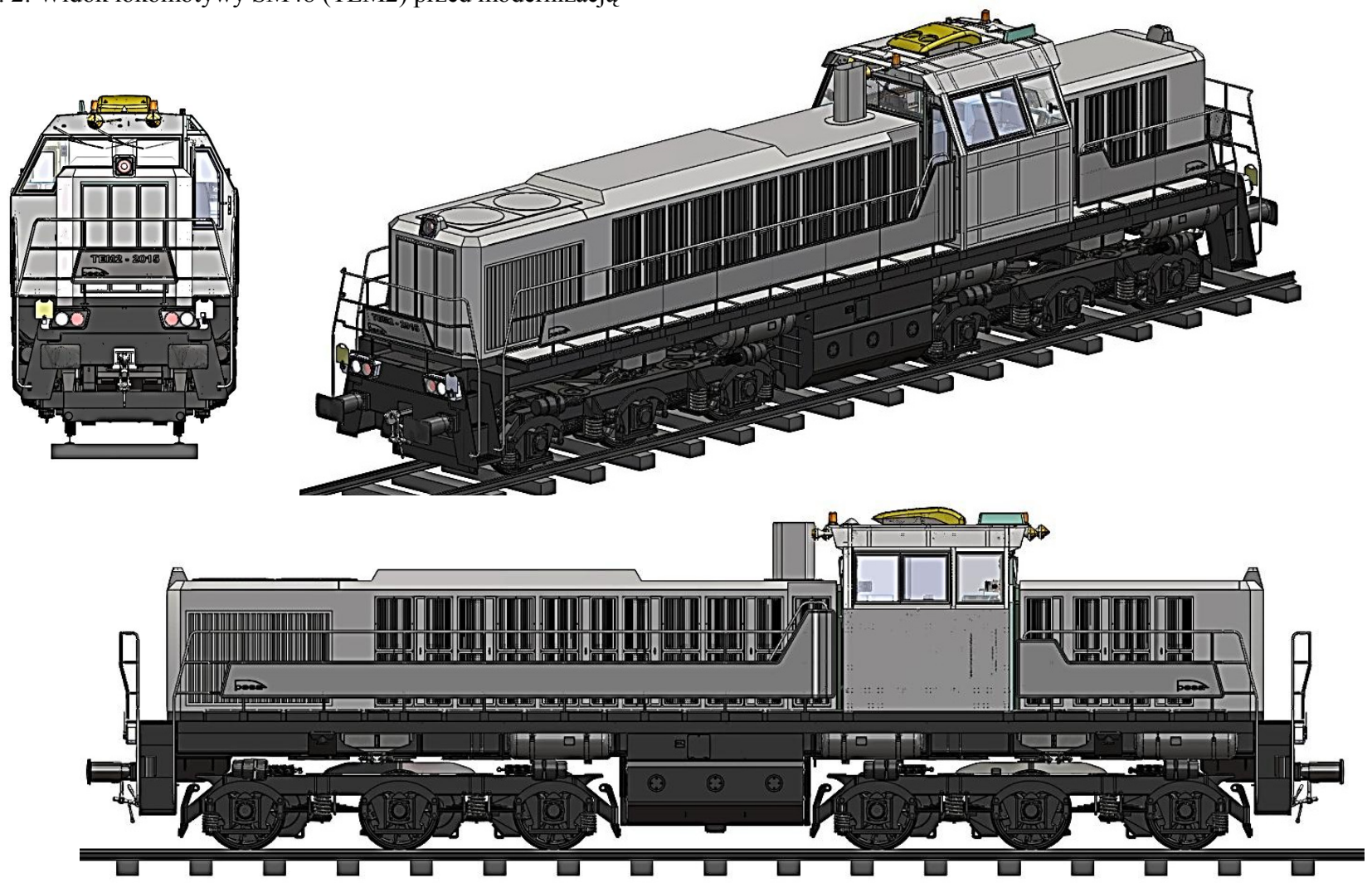

Rys. 3. Widok lokomotywy 19D serii SM48 po modernizacji
4. Główne modyfikacje znacząco ograniczające negatywny wpływ lokomotywy 19D na środowisko naturalne

Zmodernizowane lokomotywy będą charakteryzowały się zmniejszonym negatywnym wpływem na środowisko dzięki wprowadzeniu następujących zmian:

- zastosowanie nowego agregatu prądotwórczego z silnikiem MTU o mocy 1500 lub 1800 kW spełniającego wymagania Dyrektyw Unii Europejskiej w zakresie minimalnego oddziaływania na środowisko naturalne (zmniejszenie emisji substancji szkodliwych takich jak $\mathrm{CO}, \mathrm{HC}, \mathrm{NO}_{\mathrm{x}}$ oraz gazów cieplarnianych) [1], zmniejszenie zużycia paliw i środków smarnych oraz wydłużenie przebiegów międzyprzeglądowych i międzynaprawczych.

Widok ogólny agregatu prądotwórczego przedstawiamy na rys. 4.

Przykładowy wykres emisji spalin dla silnika spalinowego typu PD1M $820 \mathrm{~kW}$ zabudowanego w lokomotywie podlegającej modernizacji tj. SM48 (TEM2) przedstawiono na rys. 5.

Jak widać dotychczasowy silnik spalinowy typu PD1M lokomotywy podlegającej modernizacji SM48 (TEM2) spełnia wyłącznie limity emisji spalin substancji szkodliwych do atmosfery określonych w normie ORE B13. 


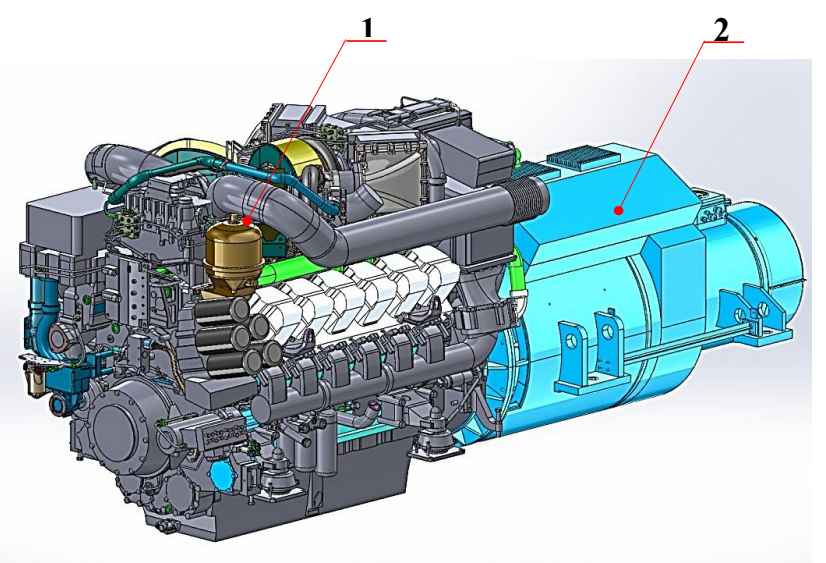

Rys. 4. Widok ogólny agregatu prądotwórczego 1 - silnik MTU; 2 - zespół prądotwórczy

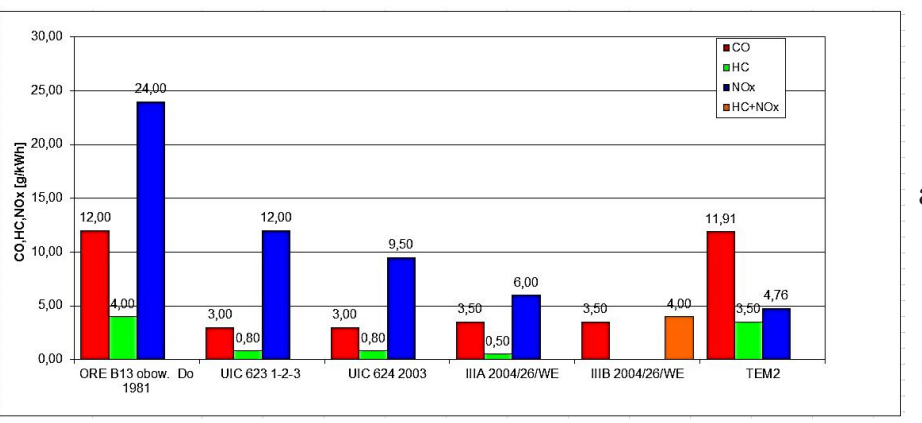

Rys. 5. Przykładowa emisja spalin dla silnika spalinowego lokomotywy SM48 (TEM2)

- zastosowanie układu chłodzenia z 2 wentylatorami firmy MAHLE Industry

Zastosowanie układu przewietrzeniu bloków chłodzących dwoma wentylatorami będzie miało pozytywny wpływ na ograniczenie hałasu. Widok ogólny na układ chłodzenia przedstawiono na rys. 6 .

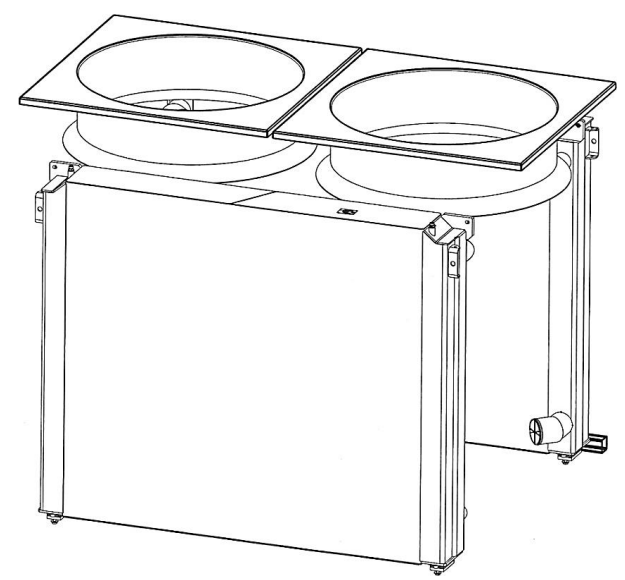

Rys. 6. Układ chłodzenia firmy MAHLE Industry z dwoma wentylatorami

- zastosowanie wentylatorów wentylacji silników trakcyjnych $\mathrm{z}$ dodatkową izolacją akustyczną.

W warunkach zwartej zabudowy urządzeń i instalacji z udziałem wentylatorów niejednokrotnie brak miejsca na zabudowę obudowy aku- stycznej w sposób umożliwiający łatwy dostęp do urządzeń. Często w takich przypadkach niemożliwy jest remont wentylatorów bez całkowi-tego demontażu obudowy.

Rozwiązaniem zapewniającym wówczas ograniczenie hałasu emitowanego przez korpus wentylatorów przy jednoczesnym zapewnieniu łatwego i szybkiego dostępu jest zamontowanie izolacji akustycznej bezpośrednio na korpusie.

Izolacje mogą być montowane na stałe do korpusu lub w postaci demontowalnych paneli. Właściwy dobór materiału akustycznego uwzględniający widmo akustyczne emitowanego hałasu, pozwala osiaggnąc dużą skuteczność przy niskich nakładach finansowych.

Widok proponowanych wentylatorów przedstawiono na rys. 5 .
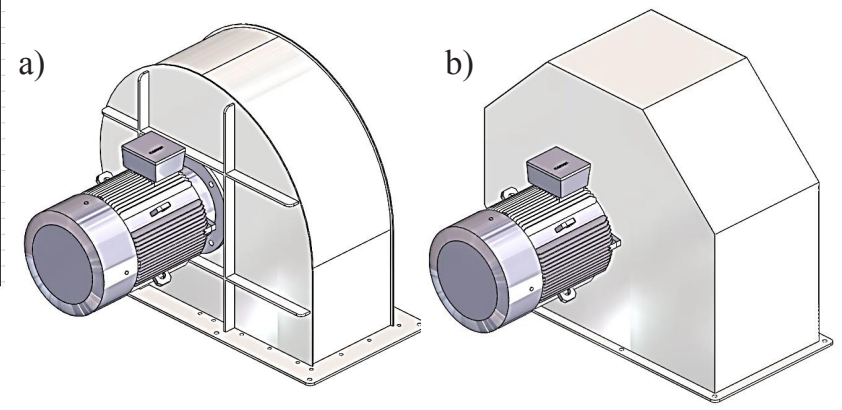

Rys. 7. Wentylator silników trakcyjnych a) bez izolacji; b) z izolacją

- zastosowanie wibraizolatorów przy zabudowie poszczególnych urządzeń, układów

Stosowanie wibroizolatorów do urządzeń, maszyn, przyczynia się zmniejszeniu hałasu i drgań przenoszonych z urządzeń do otoczenia. Skuteczność wykorzystania zależy od trafności wyboru odpowiednich wibroizolatorów.

Wibroizolatory mogą pracować zarówno na ściskanie jak i rozciaganie. Przez właściwości sprężysto-thumiące stanowią izolację dźwiękową i zmniejszają przenoszoną na podłoże ampli-tudę obciążenia dynamicznego.

Na modernizowanej lokomotywie 19D (SM48) przewidziano zastosowanie wibroizolatorów głównie przy posadowieniu zespołu prądotwórczego, i w układzie posadowienia modułu kabiny maszynisty.

Z uwagi na drgania występujące na lokomotywie, planuje się zastosowanie wibroizolatorów również przy innych urządzeniach pomocniczych np. przy zabudowie urządzeń elektrycznych. 


\section{Podsumowanie}

Platforma lokomotywy 19D (SM48 po modernizacji) będzie cechować się parametrami bardziej przyjaznymi dla środowiska. Pojazdy będą posiadały znacznie obniżoną emisję $\mathrm{CO}_{2}$ do atmosfery dzięki zastosowaniu nowoczesnych silników spełniających wymagania poziomu IIIB a także obniżeniem emisji substancji szkodliwych zawartych w spalinach (takich jak $\mathrm{CO}, \mathrm{HC}, \mathrm{NO}_{\mathrm{x}}$ i cząstki stałe $\mathrm{PH}$ ). Nastapi redukcja hałasu wewnętrznego i zewnętrznego oraz drgań. Zastosowane nowoczesne układy energoelektryczne zapewnią poprawną kompatybilność elektromagnetyczna.

\section{Literatura}

[1] Marciniak Z., Pielecha I.: Wymagania w zakresie ograniczenia emisji toksyczności składników spalin przez spalinowe pojazdy trakcyjne. TTS 11-12/2006.

[2] Marciniak Z.: Modernizacja lokomotywy spalinowej tури M62 w oparciu o silnik 12CzN26/26 - konstrukcja

$i$ wyniki badań. Technika Transportu Szynowego, $2007 \mathrm{nr} 1 \mathrm{i} 2$.

[3] Marciniak Z.: Modernizacja lokomotyw spalinowych - stan obecny i zamierzenia. Materiaty XVIII Konferencji Naukowej „Pojazdy Szynowe”, Katowice Ustroń, 2008.
[4] Marciniak Z: Doposażenie, remotoryzacja oraz modernizacja liniowych $i$ manewrowych lokomotyw spalinowych $w$ Pesa Bydgoszcz S.A., Technika Transportu Szynowego, $2009 \mathrm{nr} 4 \div 5$.

[5] Marciniak Z.: Polonizacja, remotoryzacja $i$ modernizacja lokomotyw spalinowych eksploatowanych w kraju. Pojazdy Szynowe, 2010, $n r 1$.

[6] Marciniak Z.: Nowe rozwiazania $i$ uklady $w$ zmodernizowanej lokomotywie spalinowej typu 301Dd serii ST45 do ruchu towarowego. Materiaty XIX Konferencji Naukowej Pojazdy Szynowe, Targanice k/Andrychowa, 2010.

[7] Marciniak Z.: Projekty modernizacyjne spalinowych lokomotyw liniowych i manewrowych wykonanych w Instytucie Pojazdów Szynowych, Logistyka, 2010 $n r 4$.

[8] Marciniak Z.: Zmodernizowane w ostatnich latach lokomotywy elektryczne $i$ spalinowe $w$ Polsce. Technika Transportu Szynowego, 2011 nr 4. 